\title{
ANALISIS FUNDAMENTAL DALAM PENGAMBILAN KEPUTUSAN INVESTASI SAHAM PERUSAHAAN PERKEBUNAN PERIODE 2008-2015
}

\author{
Irma Dwi Pratiwi ${ }^{1}$ \\ Universitas Pendidikan Indonesia \\ (irma.dwi@student.upi.edu) \\ Nugraha $^{2}$ \\ Universitas Pendidikan Indonesia \\ (nugraha@upi.edu)
}

\begin{abstract}
Objective - For fundamental analysis and to know the description of Earning Per Share and Price Earning Ratio as a basis for consideration in decision making of stock investment in plantations sub-sector period 2008-2015.

Design/methodology/approach - This type of research is descriptive method with a total sample of 7 metal and allied sub-sector companies listed on the Indonesian Stock Exchange. The analysis technique used is fundamental analysis with EPS and PER approaches. The design of this research is the method of time series design with a period of research for 8 years.

Findings - Based on the results of fundamental analysis with EPS and PER approach can effectively assist investors in assesing the company's stock on making decision of stock investment in plantations sub sector.

Originality/value - The difference in this study lies in the object of research, study time, measuring tools, literature used, the theory used and the results of research.
\end{abstract}

Keywords: Fundamental analysis, Investment Decision Making, Stocks, Earning Per Share (EPS), Price Earning Ratio (PER), Intrinsic Value

Article Type: Case Study

\section{PENDAHULUAN}

Keputusan investasi merupakan keputusan yang paling penting bagi pengelolaan keuangan sebagai salah satu bidang kajian ekonomi yang dapat memberikan solusi terhadap berbagai macam resiko dan ketidakpastian dalam investasi keuangan yang dihadapi oleh setiap individu, organisasi bisnis dan perusahaan, serta pemerintah (Afriyeni, 2013). Pengambilan keputusan investasi telah diakui secara luas sebagai salah satu faktor primer yang mempengaruhi kemampuan keuangan dan kesejahteraan keuangan (Janor \& Yakob, 2016). Keputusan investasi di perusahaan diakui sebagai sumber utama penciptaan nilai, melalui investasi dapat membentuk modal yang mengarah pada kelangsungan operasional perusahaan, pembaruan pasokan dan posisi kompetitif yang unggul sehingga menjadi kesempatan bagi perusahaan dalam pertumbuhan dan kenaikan laba (Pereira, Securato, \& de Sousa, 2016).

Penawaran dan permintaan investasi di pasar modal menunjukkan kegiatan investor dalam mengambil keputusan dana yang akan mereka investasikan, namun keputusan investasi itu sendiri menjadi permasalahan bagi investor karena seringnya mengalami kesulitan dalam proses pengambilan keputusan (Jiang \& Xie, 2016). Permasalahan lain yaitu persaingan bisnis yang semakin meningkat pada saat ini dan menjadi tantangan bisnis bagi setiap perusahaan (Nurpriyanti \& Hurriyati, 2016). Mengingat begitu pentingnya sebuah keputusan, maka perusahaan dituntut untuk terus berupaya melakukan strategi-strategi dalam menghadapi pesaing (Nurrahman \& Utama, 2016).

Penyebab permasalahan yang terjadi yaitu sekretaris perusahaan PT Bursa Efek Indonesia, Irmawati Amran mengatakan bahwa terdapat penurunan dengan ekspektasi investasi secara global karena spekulasi atas kenaikan suku bunga acuan Bank Sentral Amerika Serikat atau The $\mathrm{Fed}$, adanya tren penurunan harga minyak mentah dunia, serta tekanan perlambatan ekonomi global yang khususnya berasal dari negara China (market.bisnis.com (19/07/2016)).

Kondisi ini berpengaruh terhadap pertumbuhan perekonomian Indonesia. Bank Dunia mengatakan bahwa akibat melemahnya pertumbuhan investasi dan ekspor, pertumbuhan ekonomi Indonesia pada tahun 2015 hanya mencapai 5,2 \% yang berdampak pada sektor lainnya dan keuntungan negara serta kurangnya kepercayaan investor baik investor asing atau 
domestik (worldbank.org (08/12/2015)). Kepala Badan Koordinasi Penanaman Modal (BKPM) Franky Sibarani (koran-sindo.com (07/01/15) memaparkan, pertumbuhan investasi di sektor hilirisasi pertanian, peternakan sapi, dan hortikultura selama 10 tahun terakhir lebih rendah dibanding pertumbuhan rata-rata produk domestik bruto (PDB) Indonesia. Penurunan investasi sektor pertanian, peternakan, kehutanan dan perikanan di Indonesia selama 10 tahun tersebut maka menunjukkan bahwa rendahnya minat investasi di tahun 2015, sehingga sektor pertanian dan perkebunan merupakan salah satu daftar negatif investasi (DNI) yang direvisi oleh pemerintah (nefonews (23/02/2015). Salah satu diantara instrumen pasar modal yang dapat dipilih oleh investor untuk menginvestasikan dananya adalah saham. Sektor saham perkebunan masih cenderung lesu sepanjang 2015, tercatat kinerja sektor saham perkebunan melemah 32,02 persen ke level 1.596,27 secara year to date (bisnis.liputan6.com (03/08/2015)).

Salah satu emiten perkebunan sawit terbesar di Indonesia adalah PT Astra Agro Lestari Tbk (AALI). Laba bersih AALI merosot tajam hingga $75,2 \%$ secara tahunan (year on year/yoy) sebesar Rp 619,1 miliar dari Rp 2,504 triliun pada tahun 2015, sehingga laba per saham turun dari Rp 1.590,4 menjadi Rp. 93,15. Penurunan itu diikuti emiten emiten lain, seperti PT London Sumatra Indonesia Tbk turun 33,9 \% (investasi.kontan.co.id (24/02/2016)). Berikut perkembangan harga saham perusahaanperusahaan yang termasuk dalam sub sektor perkebunan:

\section{Gambar 1}

Perkembangan Harga Saham Perusahaan Sub Sektor Perkebunan Periode 2008-2015

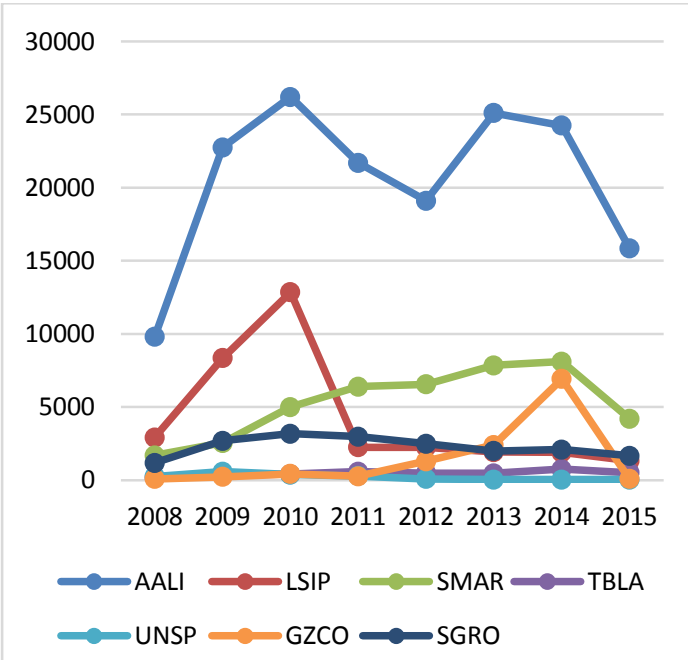

Sumber : duniainvestasi.com (data diolah)
Berdasarkan Gambar 1 menunjukkan harga saham perusahaan industri perkebunan mengalami penurunan dan beberapa stagnan tidak berkembang tinggi. Pada tahun 2015 harga saham AALI tutup pada 15850 rupiah turun 9950 rupiah dari harga sebelumnya 24.250 rupiah di 2014 , LSIP tutup pada 1320 rupiah, SMAR tutup pada 4200 rupiah, SGRO tutup pada 1665 rupiah, GZCO tutup pada 89 rupiah, TBLA tutup pada 510 rupiah, dan UNSP penutup harga saham terkecil yaitu sebesar 50 rupiah. Rendahnya harga saham mengindikasikan bahwa permintaan investasi berkurang di pasaran, sedangkan investasi merupakan bagian penting dalam pembangunan ekonomi nasional.

Kondisi tersebut memacu perusahaan untuk lebih dapat mengerti dan memperhatikan setiap keputusan yang akan diambil (Haekal \& Widjajanta, 2016). Perusahaan yang cerdas adalah perusahaan yang mampu melihat tahapan keputusan penggunanya (Aprilia \& Wibowo, 2016). Baik itu perusahaan maupun investor yang akan menginvestasikan dananya. Faktor yang mempengaruhi individu dalam berperilaku adalah karena ada dorongan dari internal maupun dari eksternal yang akan mempengaruhi individu dalam menentukan pilihan sehingga akan berdampak pada keputusan yang akan dibuat (Yuliana \& Tarmedi, 2017). Salah satu faktor internal itu sendiri yaitu sebuah kepercayaan. Kepercayaan yang dimiliki oleh individu dapat mempengaruhi sikap atau perilaku secara langsung termasuk dalam membuat sebuah keputusan (Haekal \& Widjajanta, 2016). Kepercayaan itu muncul ketika individu menganalisis sendiri dan melakukan penilaian sebagai dasar pertimbangan keputusan.

Pengambilan keputusan investasi dapat dilakukan oleh investor setelah melakukan penilaian harga saham dan harus melakukan keputusan investasi secara tepat dan menguntungkan. Ketika harga intrinsik dari sebuah saham telah diketahui serta membandingkan dengan harga pasar saham sehingga diperoleh suatu kesimpulan investor akan membeli, menjual atau mempertahankan saham tersebut (Rahman, 2016).

Investor umumnya melakukan analisis investasi dengan menggunakan analisis fundamental, analisis teknis dan penilaian. Analisis keuangan biasanya menggunakan dua teknik analisis yaitu analisis ternikal dan analisis fundamental (Campanella, Mustilli, \& Angelo, 2016). Analisis teknikal merupakan analisis sekuritas dengan menggunakan grafik harga dan volume historis (Sulistiawan \& Liliana, 2007). Analisis fundamental adalah analisis memperkirakan harga saham di masa yang akan datang dengan mengestimasi nilai faktor-faktor 
fundamental yang mempengaruhi harga saham di masa yang akan datang dan menerapkan hubungan variabel-variabel tersebut sehingga diperoleh taksiran harga saham (Suad, 2003).

EPS dan PER merupakan dua alat ukur yang sering digunakan untuk mengevaluasi saham. EPS atau laba per lembar saham adalah tingkat keuntungan bersih untuk tiap lembar sahamnya yang mampu diraih perusahaan pada saat menjalankan operasinya. Laba per lembar saham atau EPS di peroleh dari laba yang tersedia bagi pemegang saham biasa dibagi dengan jumlah rata-rata saham biasa yang beredar. PER adalah hubungan antara pasar saham dengan EPS saat ini yang digunakan secara luas oleh investor sebagai panduan umum untuk mengukur nilai saham. PER menunjukkan berapa kali lipat para investor di pasar mau membayar untuk setiap rupiah laba per saham yang dihasilkan perusahaan, sehingga PER mencerminkan daya tarik sebuah saham.

Adapun tujuan penelitian ini adalah untuk melihat bagaimana gambaran earnings per share dan gambaran price earning ratio pada Sub Sektor Perusahaan Perkebunan periode 20082015 dalam pengambilan keputusan investasi saham.

\section{KAJIAN PUSTAKA}

Pasar modal hakikatnya adalah jaringan tatanan yang memungkinkan pertukaran klaim jangka panjang, penambahan financial asset, hutang dan pada saat yang sama, memungkinkan investor untuk mengubah dan menyesuaikan portofolio investasi melalui pasar sekunder, (Anoraga \& Pakarti, 2008:6). Pengertian pasar modal menurut Undang-undang Pasar Modal No. 8 Tahun 1995 dalam Haming \& Basamalah (2010:354) yaitu, sebagai suatu kegiatan yang bersangkutan dengan penawaran umum dan perdagangan efek, perusahaan publik yang berkaitan dengan efek yang diterbitkannya, serta lembaga dan profesi yang berkaitan dengan efek.

Pasar Modal di Indonesia memiliki beberapa instrumen yang diperjualbelikan. Instrumen-instrumen tersebut dapat digolongkan dalam tiga kelompok besar, yaitu instrumen yang tergolong ke dalam ekuitas, obligasi, dan derivatif. Salah satu bidang investasi pada pasar modal yang cukup menarik namun tergolong berisiko tinggi adalah investasi saham. Saham perusahaan publik, sebagai komoditi investasi tergolong berisiko tinggi, karena sifat komoditinya yang sangat peka terhadap perubahan yang terjadi, baik di dalam negeri, perubahan di bidang politik, ekonomi, dan moneter. Perubahan tersebut dapat berdampak positif yang berarti naiknya kurs saham atau berdampak negatif yang berarti turunnya kurs saham.
Keputusan Investasi adalah hasil akhir dari penilaian harga saham yang dilakukan dengan cara membandingkan nilai intrinsik (intrinsic value) dengan harga pasar saat ini yaitu closing price saham yang diteliti (Kurniaty, Hidayat, \& Endang, 2016). Atik (2012) memaparkan keputusan investasi adalah keputusan pada investasi yang memiliki efek besar pada kinerja keuangan dan operasional jangka panjang perusahaan dengan berdampak besar pada keunggulan kompetitif perusahaan. Melakukan keputusan investasi dalam bentuk saham, investor harus melakukan analisis terhadap faktor yang mempengaruhi kondisi perusahaan emiten, sehingga dapat meminimalisasi kerugian yang dapat timbul dari adanya fluktuasi pertumbuhan dan perkembangan emiten yang bersangkutan. Analisis yang dapat dilakukan dalam memilih saham, ada dua aspek yang sering digunakan yaitu aspek fundamental dan aspek teknikal (Haming \& Basamalah, 2010:374-375).

Individu yang menerapkan strategi investasi secara aktif dapat menggunakan analisis teknis, dan analisis fundamental. Analisis teknis (technical analysis) atau charting mencari pola dalam sejarah harga atau volume sebuah saham untuk memprediksi pererakan harga saham di masa depan. Analisis fundamental (fundamental analysis) lebih luas diterima dan diaplikasikan yang merupakan proses menentukan nilai perusahaan dengan menganalisis dan menginterpretasikan faktor-faktor kunci untuk ekonomi, industri, perusahaan dengan bagian utama analisisnya evaluasi atas posisi dan kinerja keuangan perusahaan (Subramanyam \& Wild, 2010:18).

Menurut Subramanyam (2014:27-28) memaparkan lima set alat analisis fundamental dalam keuangan yaitu: 1) laporan keuangan komparatif; 2) ukuran umum laporan keuangan; 3) analisis rasio; 4) analisis arus kas; dan 5) penilaian. Analisis rasio adalah salah satu alat yang paling populer dan banyak digunakan analisis keuangan. Manurung (2008) mengatakan bahwa terdapat dua pendekatan dalam menilai perusahaan menggunakan analisis fundamental yaitu PER dan Earning Per Share (EPS). Sifat yang menonjol dari instrumen pasar modal memaksa investor untuk sangat bergantung pada faktor fundamental dalam mereka keputusan investasi dengan menggunakan analisis keuangan yaitu EPS dan PER (Roy, 2015). Earning per Share (EPS) merupakan perbandingan antara laba bersih setelah pajak pada tahun buku terhadap harga saham yang diterbitkan perusahaan (Hadi, 2015:134). Price Earning Ratio (PER) adalah ukuran yang paling sering dilaporkan dari nilai perusahaan dengan harga pasar perusahaan per lembar saham dibagi dengan pendapatan tahunan 
perusahaan per saham (Edmonds, McNair, Olds, \& Edmonds, 2016:615-616). Menurut Hadi (2015:136). Price Earning Ratio merupakan rasio pasar yang mengindikasikan penghargaan investor terhadap kinerja perusahaan yang ditunjukkan dalam earning per share. PER yaitu hubungan antara pasar saham dengan EPS saat ini yang digunakan secara luas oleh investor sebagai panduan umum untuk mengukur nilai saham.

Rumus untuk menghitung EPS yaitu: EPS

$$
=\frac{\text { laba bersih }}{\text { jumlah lembar saham yang beredar }}
$$

Sumber : (Fakhruddin \& Hendy, 2008)

$$
\mathrm{EPS}=\frac{\mathrm{EAT}}{\mathrm{J} \mathrm{sb}}
$$

Sumber : (Fahmi, 2015:82)

Keterangan :

EPS = Earning Per Share

$\mathrm{EAT}=$ Earning After Tax

$\mathrm{J}_{\mathrm{sb}}=$ Jumlah saham yang beredar

Rumus untuk menghitung PER yaitu:

$$
\text { PER }=\frac{\text { harga pasar saham }}{\text { laba per lembar saham }}
$$

Sumber: (Fakhruddin \& Hendy, 2008)

$$
\text { PER }=\frac{\text { MPS }}{\text { EPS }}
$$

Sumber : (Fahmi, 2015:83)

Keterangan :

$\mathrm{PER}=$ Price Earning Ratio

EPS = Earning Per Share

MPS = Market Price Per Share

Earning Per Share dapat digunakan untuk membandingkan pertumbuhan laba per saham, investor bisa melihat laba per saham perusahaan satu dengan perusahaan lainnya dan memilih perusahaan yang memiliki EPS tinggi. Pendekatan ini sering digunakan oleh investor sebagai alat analisis fundamental, namun EPS ini memiliki kekurangan yaitu tidak bisa digunakan untuk menentukan wajar tidaknya harga saham perusahaan. Oleh karena itu, rasio EPS biasanya dikombinasikan dengan Price Earning Ratio untuk menghitung harga wajar saham. Penilaian keputusan investasi saham menggunakan analisis fundamental dengan pendekatan EPS dan PER dapat secara efektif membantu investor dalam proses mengambil keputusan karena investor mengetahui tingkat kesehatan keuangan perusahaan dan dividend growth, maka besarnya harga saham yang diharapkan atau nilai intrinsiknya dapat ditentukan ke dalam saham undervalued, overvalued atau correctly valued sebagai dasar pertimbangan investor dalam melakukan investasi saham dengan keputusan yang tepat.

\section{METODE PENELITIAN}

Penelitian ini menggunakan pendekatan manajemen keuangan khususnya mengenai analisis fundamental dalam membuat keputusan investasi. Objek penelitian yang diteliti yaitu menganalisis penilaian investasi saham dalam pengambilan keputusan investasi berdasarkan analisis fundamental dengan pendekatan EPS dan PER dari tahun 2008-2015. Perusahaanperusahaan industri perkebunan yang menawarkan saham selama 8 tahun yaitu AALI, LSIP, SMAR, TBLA, UNSP, GZCO, dan SGRO.

Penelitian ini dilakukan dalam kurun waktu 8 tahun yaitu mulai dari tahun 2008 sampai dengan tahun 2015, maka desain penelitian yang digunakan adalah time series design.

Teknik pengumpulan data yang digunakan dalam penelilian ini adalah purposive sampling atau pengambilan data dengan tujuan tertentu, sedangkan teknik analisis data yang dilakukan adalah analisis deskriptif. Implementasi jenis penelitian deskriptif dalam penelitian ini adalah untuk menggambarkan EPS dan PER perusahaan sub sektor perkebunan tahun 2008-2015. Data yang digunakan dalam penelitian ini adalah data sekunder, karena tidak memungkinkan untuk memperoleh data tersebut secara langsung atau melalui media perantara yaitu data historis tentang harga saham dan laporan keuangan periode 2008-2015. Tahapan dalam analisis data yang akan dilakukan sesuai dengan penelitian (Rahman et al., 2016) yaitu mendeskripsikan perkembangan kondisi keuangan perusahaan dengan menggunakan variabel fundamental yang meliputi: ROE, EPS, DPS dan DPR, lalu menghitung tingkat pertumbuhan expected earnings (earnings growth rate atau g), menentukan estimated Earnings per Share (EPS), estimated Dividend per Share (DPS), nilai expected return (k), selanjutnya menghitung estimated PER dan harga intrinsik saham, terakhir menilai kondisi saham dengan membandingkan harga intrinsik dengan harga pasar saham dan mengklasifikasikannya serta membuat keputusan investasi saham yang akan diambil.

\section{Tabel 1}

Pedoman Untuk Keputusan Investasi Dengan Metode Price Earning Ratio

\begin{tabular}{clcc}
\hline No & Keterangan & Kondisi Saham & Keputusan Investasi \\
\hline 1. & $\begin{array}{l}\text { Nilai intrinsik } \\
>\text { Harga Pasar }\end{array}$ & Undervalued & Membeli Saham \\
2 & $\begin{array}{l}\text { Nilai Intrinsik } \\
<\text { Harga Pasar }\end{array}$ & Overvalued & Menjual Saham \\
3 & $\begin{array}{l}\text { Nilai } \\
\text { Intrinsik= } \\
\text { Harga Pasar }\end{array}$ & $\begin{array}{c}\text { Correctly } \\
\text { Valued }\end{array}$ & Menahan Saham \\
& & \\
\hline
\end{tabular}

Sumber: Husnan (2005:233) 


\section{HASIL PENELITIAN DAN PEMBAHASAN}

Analisis fundamental dapat membantu investor untuk menilai sebuah perusahaan dengan melihat gambaran keuntungan dan nilai intrinsik dari perusahan tersebut. Berikut merupakan hasil gambaran dan perhitungan analisis fundamental dengan pendekatan earning per share dan price earning ratio:

GAMBAR 2

Perkembangan Earning Per Share Perusahaan Sub Sektor Perkebunan Periode 2008-2015

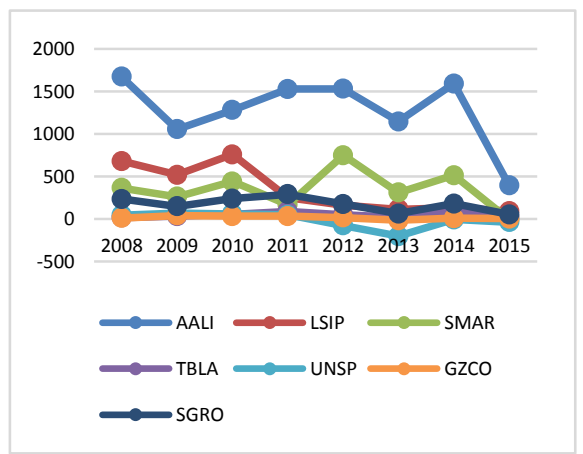

Sumber: idx.co.id (data diolah)

Berdasarkan Gambar 2 perkembangan EPS perusahaan sub sektor perkebunan dari tahun 2008-2015 terlihat bahwa perusahaan Astra Agro Lestari Tbk merupakan perusahaan yang memiliki EPS tertinggi dibandingkan dengan perusahaan lainnya. Perusahaan yang memiliki EPS terendah yaitu Bakrie Sumatra Pantations Tbk. Berdasarkan gambaran EPS perusahaanperusahaan tersebut maka keputusan investasi untuk membeli saham yang terbaik yaitu AALI.

\section{GAMBAR 3}

Perkembangan Price Earning Ratio Perusahaan Sub Sektor Perkebunan Periode 2008-2015

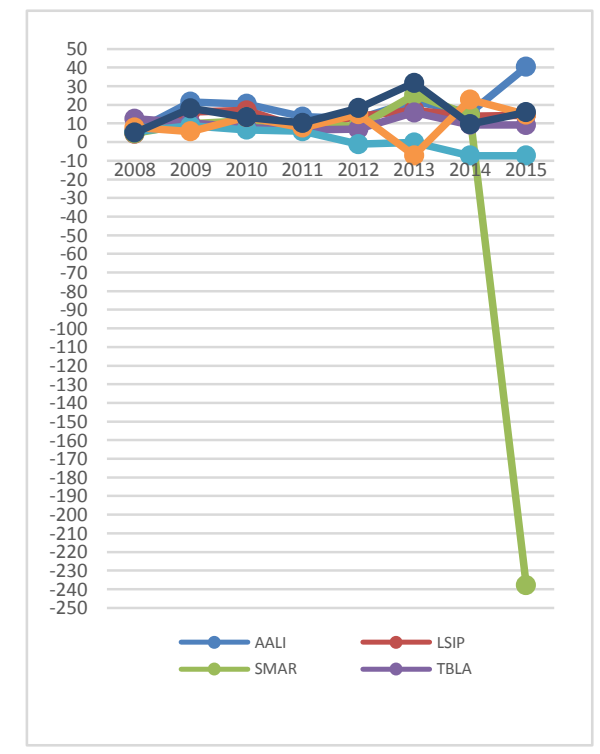

Sumber: idx.co.id (data diolah)
Berdasarkan Gambar 3 perkembangan PER perusahaan sub sektor perkebunan dari tahun 2008-2015 secara keseluruhan terlihat cenderung bergerak stagnan. Smart Tbk mengalami penurunan PER secara drastis yang terjadi pada tahun 2015 yaitu sebesar 223,44 X dari tahun 2014 14,54 X menjadi -237,98 X. Berdasarkan gambaran PER perusahaan-perusahaan tersebut maka keputusan investasi untuk membeli saham yang terbaik yaitu AALI.

GAMBAR 4

Perbandingan EPS dan PER Perusahaan Sub Sektor Perkebunan 2015

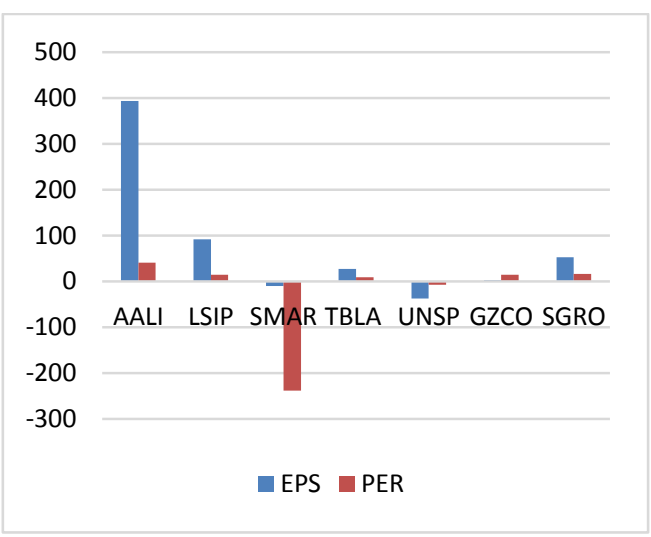

Sumber: idx.co.id (data diolah)

Berdasarkan Gambar 4 perusahaan AALI memiliki peringkat tertinggi dibandingkan dengan perusahaan yang lain dengan EPS sebesar Rp. 393 dan PER sebesar 40,32 X. Berdasarkan EPS perusahaan yang menduduki peringkat kedua yaitu LSIP sebesar Rp. 91, ketiga SGRO sebesar Rp. 52, keempat TBLA sebesar Rp. 27, kelima GZCO sebesar Rp. 3, keenam SMAR sebesar Rp. 10, dan terakhir UNSP sebesar Rp. -37.

Berdasarkan PER perusahaan yang menduduki peringkat kedua yaitu SGRO sebesar 15,98 X, ketiga GZCO sebesar 14,76 X, keempat LSIP sebesar 14,38 X, kelima TBLA sebesar 9,1 $\mathrm{X}$, keenam UNSP sebesar -7,27 X, dan terakhir SMAR sebesar $-237,98$ X. Berdasarkan perbandingan gambaran EPS dan PER perusahaan-perusahaan tersebut maka keputusan investasi untuk membeli saham yang terbaik yaitu AALI.

\section{Penilaian Keputusan Investasi Saham Berdasarkan Nilai Intrinsik dengan Kombinasi Earning Per Share dan Price Earning Ratio \\ Rasio Earning Per Share dapat dikombinasikan dengan Price Earning Ratio untuk menghitung harga wajar saham. Penilaian keputusan investasi saham menggunakan analisis fundamental dengan pendekatan EPS dan PER}


dapat secara efektif membantu investor dalam proses mengambil keputusan karena investor mengetahui tingkat kesehatan keuangan perusahaan dan dividend growth dengan mengetahui nilai intrinsik saham perusahaan tersebut, maka besarnya harga saham yang diharapkan atau nilai intrinsiknya dapat ditentukan ke dalam saham undervalued, overvalued atau correctly valued sebagai dasar pertimbangan investor dalam melakukan investasi saham dengan keputusan yang tepat.

Tahapan dalam analisis data yang akan dilakukan sesuai dengan penelitian (Rahman et al., 2016) yaitu mendeskripsikan perkembangan kondisi keuangan perusahaan dengan menggunakan variabel fundamental yang meliputi: ROE, EPS, DPS dan DPR, lalu menghitung tingkat pertumbuhan expected earnings (earnings growth rate atau g), menentukan estimated Earnings per Share (EPS), estimated Dividend per Share (DPS), nilai expected return (k), selanjutnya menghitung estimated PER dan harga intrinsik saham, terakhir menilai kondisi saham dengan membandingkan harga intrinsik dengan harga pasar saham dan mengklasifikasikannya serta membuat keputusan investasi saham yang akan diambil.

Hasil pengolahan data perhitungan analisis fundamental menggunaka kombinasi pendekatan earning per share dan price earning ratio sub sektor perusahaan perkebunan periode 2008-2015 untuk mengetahui nilai intrinsik saham perusahaan tersebut dapat dilakukan dengan menggunakan software Microsoft Excel 2013. Berikut tabel 2 dan 3 keputusan investasi saham perusahaan perkebunan yang terdaftar di BEI berdasarkan nilai intrinsik:

TABEL 2

Keputusan Investasi Saham Perusahaan Perkebunan yang Terdaftar di BEI

Berdasarkan Nilai Intrinsik Tahun 2014

\begin{tabular}{|c|c|c|c|c|}
\hline $\begin{array}{c}\text { Kode } \\
\text { Saham } \\
\end{array}$ & $\begin{array}{c}\text { Nilai } \\
\text { Intrinsik }\end{array}$ & $\begin{array}{l}\text { Harga } \\
\text { Pasar }\end{array}$ & $\begin{array}{l}\begin{array}{l}\text { Kondisi } \\
\text { Saham }\end{array} \\
\end{array}$ & $\begin{array}{c}\text { Keputusan } \\
\text { Investasi }\end{array}$ \\
\hline AALI & 25100 & 24250 & Undervalued & Membeli \\
\hline LSIP & 1930 & 1890 & Undervalued & Membeli \\
\hline SMAR & 7850 & 8100 & Overvalued & Membeli \\
\hline TBLA & 470 & 775 & Overvalued & Membeli \\
\hline UNSP & 50 & 50 & $\begin{array}{c}\text { Correctly } \\
\text { Valued }\end{array}$ & Menahan \\
\hline GZCO & 2403 & 6926 & Overvalued & Membeli \\
\hline SGRO & 2000 & 2100 & Overvalued & Membeli \\
\hline
\end{tabular}

Sumber: Data diolah (2016)

Berdasarkan Tabel 2, dapat digunakan untuk memudahkan investor mengetahui kondisi saham perusahaan yang akan diinvestasikan. PT Astra Agro Lestari Tbk dan PT London Sumatera Indonesia Tbk berada pada kondisi undervalued atau harga saham dinilai murah karena nilai intrinsik saham lebih besar daripada harga pasarnya. Keputusan investasi yang dapat direkomendasikan adalah membeli saham-saham tersebut dan bagi investor yang memiliki kepemilikan atas saham-saham tersebut diharapkan untuk bisa menambah jumlah lembar saham yang dimiliki dengan harapan memperoleh keuntungan lebih.

Smart Tbk, Tunas Baru Lampung Tbk, Gozco Plantation Tbk dan Sampoerna Agro Tbk berada pada kondisi overvalued atau harga saham dinilai mahal karena nilai intrinsik saham lebih besar daripada harga pasarnya. Keputusan investasi yang dapat direkomendasikan adalah menjual saham-saham tersebut. Bakrie Sumatra Plantations Tbk berada pada kondisi correctly valued sehingga investor dapat menahan saham tersebut.

TABEL 3

Keputusan Investasi Saham Perusahaan Sub Sektor Perkebunan yang Terdaftar di BEI Berdasarkan Nilai Intrinsik Tahun 2015

\begin{tabular}{|c|c|c|c|c|}
\hline $\begin{array}{c}\text { Kode } \\
\text { Saham } \\
\end{array}$ & $\begin{array}{c}\text { Nilai } \\
\text { Intrinsik }\end{array}$ & $\begin{array}{l}\text { Harga } \\
\text { Pasar }\end{array}$ & $\begin{array}{l}\text { Kondisi } \\
\text { Saham } \\
\end{array}$ & $\begin{array}{c}\text { Keputusan } \\
\text { Investasi }\end{array}$ \\
\hline AALI & 24250 & 15850 & Undervalued & Membeli \\
\hline LSIP & 1890 & 1320 & Undervalued & Membeli \\
\hline SMAR & 8100 & 5000 & Undervalued & Membeli \\
\hline TBLA & 775 & 500 & Undervalued & Membeli \\
\hline UNSP & 50 & 50 & $\begin{array}{c}\text { Correctly } \\
\text { Valued }\end{array}$ & Menahan \\
\hline GZCO & 6926 & 89 & Undervalued & Membeli \\
\hline SGRO & 2100 & 1665 & Undervalued & Membeli \\
\hline
\end{tabular}

Sumber: Data diolah (2016)

Berdasarkan Tabel 3, dapat digunakan untuk memudahkan investor mengetahui kondisi saham perusahaan yang akan diinvestasikan. PT Astra Agro Lestari Tbk, PT London Sumatera Indonesia Tbk, Smart Tbk, Tunas Baru Lampung Tbk, Gozco Plantation Tbk dan Sampoerna Agro Tbk berada pada kondisi undervalued atau harga saham dinilai murah karena nilai intrinsik saham lebih besar daripada harga pasarnya. Keputusan investasi diambil adalah membeli saham atau menambah jumlah lembar saham yang dimiliki dengan harapan memperoleh keuntungan lebih. Perusahaan lainnya yaitu, Bakrie Sumatra Plantations Tbk berada pada kondisi correctly valued sehingga investor dapat menahan saham tersebut.

\section{GAMBAR 5}

Perbandingan Nilai Intrinsik Perusahaan Sub Sektor Perkebunan Tahun 2014 dan 2015

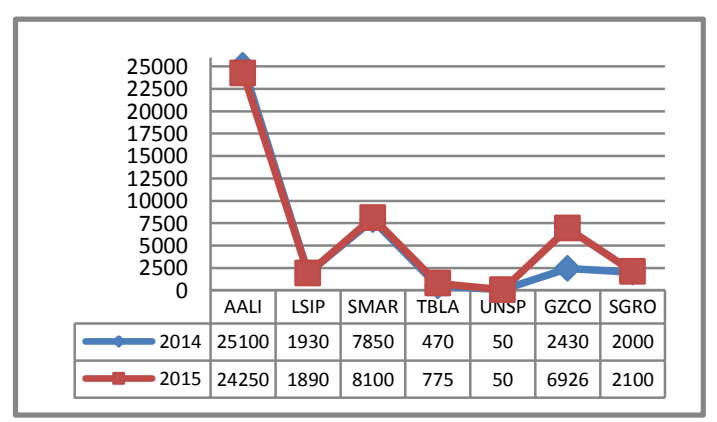


Berdasarkan Gambar 5 menunjukkan terjadinya penurunan nilai intrinsik pada saham AALI dan LSIP. Nilai intrinsik AALI turun sebesar 850. Saham UNSP tidak terjadi perubahan nilai intrinsik yaitu tetap sebesar 50 . Peningkatan nilai intrinsik terjadi pada saham SMAR sebesar 250, TBLA sebesar 305, GZCO sebesar 4496 dan SGRO sebesar 100.

\section{TEMUAN HASIL PENELITIAN}

Berdasarkan hasil penelitian mengenai pengambilan keputusan investasi saham berdasarkan analisis fundamental dengan menggunakan EPS dan PER pada perusahaan sub sektor perkebunan yang terdaftar d BEI tahun 2008-2015, maka dapat diketahui bahwa analisis fundamental secara efektif dapat membantu investor dalam membuat keputusan investasi saham dengan alat analisisnya yaitu berdasarkan pendekatan earning per share dan price earning ratio. Pendekatan ini dapat digunakan untuk mengukur nilai intrinsik sebuah perusahaan sub sektor perkebunan yang akan dipilih untuk diinvestasikan, hal ini sesuai dengan konsep yang dikemukakan oleh Manurung (2008), Sitompul (2011), Haque \& Faruquee (2013), Shukla, Nerlekar, Maharaja, Savaranakumar, Roy (2015) dan Mahesh \& Kumar (2016).

Perusahaan-perusahaan sub sektor perkebunan memiliki kondisi saham undervalued adalah perusahaan yang memiliki nilai intrinsik lebih besar dibandingkan dengan harga pasarnya maka keputusan yang diambil yaitu membelinya, overvalued jika nilai intrinsik lebih kecil dibandingkan harga pasarnya maka keputusan yang diambil yaitu tidak membeli atau menjual apabila memiliki saham tersebut, atau correctly valued sama dengan harga pasar dan keputusan yang diambil yaitu menahan saham. sebagai dasar pertimbangan investor dalam melakukan investasi saham dengan keputusan yang tepat, hal ini sesuai dengan konsep yang dijelaskan oleh Sunariyah (2006) dan Rahman, Hidayat, Azizah (2016).

Berdasarkan temuan-temuan tersebut penulis memiliki keyakinan bahwa hasil penelitian ini memiliki kontribusi ilmiah terhadap pengembangan ilmu manajemen keuangan, khususnya dalam ilmu analisis fundamental untuk menilai perusahaan sebagai dasar pertimbangan keputusan investasi.

\section{KESIMPULAN}

Berdasarkan hasil penelitian yang telah dilakukan pada perusahaan sub sektor perkebunan dengan menggunakan Earning Per Share dan Price Earning Ratio untuk penilaian kondisi saham dalam melakukan keputusan investasi maka dapat diambil beberapa kesimpulan yaitu Keputusan investasi saham berdasarkan gambaran
Earning Per Share perusahaan sub sektor perkebunan yaitu untuk membeli saham yang terbaik yaitu AALI karena memiliki nilai EPS tertinggi yaitu sebesar Rp. 393 dan tidak membeli atau menjual saham UNSP (apabila memiliki saham tersebut) karena memiliki nilai EPS terendah yaitu sebesar Rp. -37 .

Keputusan investasi saham berdasarkan gambaran Price Earning Ratio (PER) perusahaan sub sektor perkebunan yaitu untuk membeli saham yang terbaik yaitu AALI karena memiliki nilai PER tertinggi yaitu sebesar 40,32 X dan tidak membeli atau menjual saham SMAR (apabila memiliki saham tersebut) karena memiliki nilai PER terendah yaitu sebesar $-237,98 \mathrm{X}$.

Berdasarkan kombinasi pendekatan EPS dan PER dalam menentukan nilai intrinsik untuk mengetahui kondisi saham perusahaan yaitu: PT Astra Agro Lestari Tbk, PT London Sumatera Indonesia Tbk, Smart Tbk, Tunas Baru Lampung Tbk, Gozco Plantation Tbk dan Sampoerna Agro Tbk berada pada kondisi undervalued atau harga saham dinilai murah karena nilai intrinsik saham lebih besar daripada harga pasarnya. Keputusan investasi yang dapat direkomendasikan adalah membeli saham-saham tersebut dan bagi investor yang memiliki kepemilikan atas saham-saham tersebut diharapkan untuk bisa menambah jumlah lembar saham yang dimiliki dengan harapan memperoleh keuntungan lebih. Perusahaan lainnya yaitu, Bakrie Sumatra Plantations Tbk berada pada kondisi correctly valued sehingga investor dapat menahan saham tersebut.

Disarankan Bagi investor yang akan berinvestasi saham sebaiknya melihat prospek dan kondisi keuangan perusahaan terlebih dahulu. Apabila investor telah memperhatikan kondisi keuangan dan prospek perusahaan, investor dapat menilai dan mengambil keputusan investasi yang dianggap lebih menguntungkan. Bagi penelitian selanjutnya agar dapat menggunakan analisis teknikal selain analisis fundamental dan pendekatan lain selain Earning Per Share (EPS) dan Price Earning Ratio (PER), agar dapat membandingkan beberapa pendekatan dan diketahui mana pendekatan yang memiliki tingkat akurasi lebih baik.

\section{DAFTAR PUSTAKA}

Afriyeni, E. (2013). Keputusan Investasi Jangka Panjang: Capital Budgeting. Jurnal Poli Bisnis, 4(1), 65-75.

Anoraga, P., \& Pakarti, P. (2008). Pengantar Pasar Modal (Revisi). Jakarta: PT Rineka Cipta.

Aprilia, L., \& Wibowo, L. A. (2016). Pengaruh Faktor Individu dan Sosial Terhadap Keputusan Menggunakan (Survei pada 
Pengguna Aplikasi Mobile Messaging di Kota Bandung). Journal of Business Management and Enterpreneurship Education, 1(1), 202-212.

Atik, A. (2012). A Strategic Investment Decision: "Internationalization of SMEs": A Multiple Appraisal Approach and Illustration with a Case Study. Scientific Research, 4(2), 146156. https://doi.org/10.4236/ib.2012.42017

Campanella, F., Mustilli, M., \& Angelo, E. D. (2016). Efficient Market Hypothesis and Fundamental Analysis: An Empirical Test in The European Securities Market. Review of Economics \& Finance No 1923-7529-201601-27-16

Edmonds, C., McNair, F., Olds, P., \& Edmonds, T. (2016). Fundamental Financial Accounting Concepts (9th intern). New York: McGraw Hill Education.

Fakhruddin, \& Hendy, M. (2008). Teori Portofolio dan Analisis Investasi. Yogyakarta: BPFE.

Haekal, A., \& Widjajanta, B. (2016). Pengaruh Kepercayaan dan Persepsi Risiko Terhadap Minat Membeli Secara Online pada Pengunjung Website Classifieds di Inonesia. Journal of Business Management and Enterpreneurship Education, 1(1), 181-193.

Haming, M., \& Basamalah, S. (2010). Studi Kelayakan Investasi Proyek \& Bisnis. Jakarta: PT. Bumi Aksara.

Haque, S., \& Faruquee, M. (2013). Impact of Fundamental Factors on Stock Price: A Case Based Approach on Pharmaceutical Companies Listed with Dhaka Stock Exchange. International Journal of Business and Management Invention, 2(9), 34-41.

Janor, H., \& Yakob, R. (2016). Financial literacy and investment decisions in Malaysia and United Kingdom: A comparative analysis, Malaysian Journal of Society and Space 12 2(2), 106-118.

Jiang, W., \& Xie, X. (2016). Stock Fundamentals Model Based on Genetic Algorithm-Rough Set. Journal of Management and Sustainability, 6(1), 206. https://doi.org/10.5539/jms.v6n1p206

Kurniaty, I., Hidayat, R. R., \& Endang, M. G. W. (2016). Analisis Fundamental untuk Menilai Kewajaran Harga Saham dengan Dividend Discount Modal (DDM) dan Price Earning Ratio (PER) sebagai Dasar Pengambilan Keputusan Investasi (Studi Pada Sub Sektor Perbankan yang Listing di BEI Periode. Jurnal Administrasi Bisnis, $33(1)$.

Mahesh, N. M., \& Kumar, S. S. (2016).
Fundamental Analysis of Selected Indian Fmcg Companies Listed in Nse of India Limited. Indian Journal of Applied Research, 6(1), 695-698. https://doi.org/2249-555X

Manurung, A. H. (2008). Financial Planner. Jakarta: Kompas.

Nurpriyanti, V., \& Hurriyati, R. (2016). Pengaruh Kinerja Co-Branding Terhadap Keputusan Pembelian (Survei pada Mini Market Penjual Es Krim Wall's Selection Oreo di Kecamatan Cikajang- Garut). Journal of Business Management and Enterpreneurship Education, 1(1), 98-114.

Nurrahman, I., \& Utama, R. D. H. (2016). Pengaruh Variasi Produk Terhadap Keputusan Pembelian (Survei pada pembeli smartphone Nokia series $\mathrm{X}$ di BEC Bandung). Journal of Business Management and Enterpreneurship Education, 1(1), 54-63.

Pereira, M. A., Securato, J. R., \& de Sousa, A. F. (2016). Effect of investments on fundamentals and market reaction on preoperational and operational Brazilian companies for the period 2006-2012, Finance And Accounting Journal Vol 51 No 1 ISSN 1984-6142. Retrieved from http://dx.doi.org/10.5700/rausp1223

Rahman, N. Z., Hidayat, R. R., \& Azizah, D. F. (2016). Keputusan Investasi dengan Pendekatan Price Earning Ratio (PER) (Studi Kasus pada Perusahaan Industri Perkebunan yang Terdaftar di Bursa Efek Indonesia Periode 2012-2014). Jurnal Administrasi Bisnis, 35(2), 207-213.

Roy, S. G. (2015). Equity Research : Fundamental and Technical Analysis. International Journal of Science and Research, 4(9). https://doi.org/2319-7064

Shukla, A., \& Nerlekar, S. (2015). Fundamental Analysis of Listed FMGC With The Help Of Ratio's. International Conference On Contemporary Issues In Accounting, Finance, Banking And Investment MIT SOB

Sitompul, K. (2011). Analisis Pengaruh FaktorFaktor terhadap Harga Saham Perusahaan Real Estate dan Properti yang terdaftar di BEI. Universitas Pendidikan Indonesia

Suad, H. (2003). Suad Husnan, 2003.Manajemen Keuangan Teori Dan Penerapan (Keputusan Jangka Pendek) (4th ed.). Yogyakarta: BPFE.

Subramanyam, K. R. (2014). Financial Statement Analysis (11 interna). New York: McGraw Hill Education.

Subramanyam, K. R., \& Wild, J. J. (2010). Financial Statement Analysis (10th ed.). Asia: McGraw Hill Education. 
Journal of Business Management Education | Volume 1, Number 3, December 2016, page. 40-48

Sulistiawan, D., \& Liliana. (2007). Analisis Teknikal Modern Perdagangan Sekuritas. Cara Praktis Memprediksi Pergerakan Harga Saham Dan Sekuritas Lainnya. Yogyakarta: Andi.

Sunariyah. (2006). Pengantar Pengetahuan Pasar Modal (5th ed.). Yogyakarta: UPP STIM
YKPN.

Yuliana, \& Tarmedi, E. (2017). Pengaruh perbedaan individu terhadap keputusan menggunakan sistem operasi linux. Journal of Business Management and Enterpreneurship Education, 1(1), 174180. 